\title{
Warunki ekologicznej równowagi naziemia i podziemia
}

\section{Conditions for the ecological balance of ground and underground environments}

\section{Streszczenie}

Żyjemy w krytycznym momencie zmian klimatycznych. Jedną z dróg poszukiwań zaradczych jest eksploracja i wykorzystanie luk urbanistycznych miast i ich niezurbanizowanego podziemia. Aby przywrócić równowagę środowiska, szuka się modelowego trójwymiarowego sposobu projektowania urbanistycznego. Jednak mimo wykorzystania doświadczeń pionierskich, każde rozwiązanie wymaga rozpoznania warunków miejscowych i dostosowania projektu do indywidualnych lokalnych potrzeb.

Słowa kluczowe: zrównoważone podziemie, chaos prawny, prawo własności, równowaga projektowa

\section{Abstract}

We are currently living in a critical moment of climate change. One of the remedial search paths is the exploration and use of urban gaps in cities and their non-urbanised underground environments. To restore the balance of the environment, a model three-dimensional approach to urban design is being sought. However, despite the use of pioneering experience, each solution requires recognition of local conditions and adaptation of the project to individual local needs.

Keywords: balanced underground environments, legal chaos, property right, design balance 


\section{ZRÓWNOWAŻONE PODZIEMIE}

Po doświadczeniu zniszczeń na powierzchni Ziemi i ich wpływu na atmosferę, zdrowie i perspektywy człowieka jesteśmy już całkowicie przekonani o konieczności wszelkich zrównoważonych działań urbanistycznych, łącznie z podziemnymi. Zarówno tych rozwojowych, jak rewitalizujących i naprawczych. Zrównoważonych to znaczy nienaruszających harmonii Ziemi lub przywracających ją między człowiekiem, humanizmem i naturą ${ }^{1}$. Nasze działania dotychczasowe natomiast stale polegają na wydobyciu i zużyciu naturalnych materiałów nieodnawialnych. Tymczasem żyjąca natura, działająca jako pracujący ekosystem, sama się potrafi całkowicie regenerować. Używamy Ziemi i jej życiodajnego podziemia do uprawy, wycinamy zasoby, wyjaławiamy monokulturami, wypalamy przemysłem, wydzieramy jej surowce i minerały, grabimy inne żyjące stworzenia - faunę i florę. Zabijamy.

Rozwój zrównoważony to przywrócenie zasobów przyszłym generacjom, planowanie i regulowanie eksploatacji w wielkościach wyrównywanych odnawianiem. To planowa kontrola i modele analiz użytkowania podziemia. To ten sam przymus odpowiedzialnego planowego urbanizowania, określonego ramami prawnymi - analogicznie jak uporządkowane działania na powierzchni. Jest tu potrzebna kompleksowa wiedza o budowie geomorfologicznej skorupy, o istniejących ekosystemach i możliwościach ich bezpiecznego wykorzystania. Niezwykle ważnym czynnikiem jest obecność wody, jej rodzaju, składu, jakości. Człowiek jest całkowicie uzależniony od wody pitnej. W swoim zadufaniu eksploratora zniszczył już i zanieczyścił ogromne zasoby wód. Sama eksploatacja kopalni różnego typu przez tysiące lat spowodowała nie tylko zmiany struktury podłoża i stosunków wodnych, ale zmiany składu mineralnego i niejednokrotnie niemożność samooczyszczania się wody. Na powierzchni większość rzek i mórz jest już zanieczyszczona, a nawet zatruta. Dalsza bezkrytyczna eksploatacja równa się samozagładzie człowieka.

Podobnie prowadzona wybiórczo działalność wydobywcza niszcząca naturalną zwartość materii podziemia spowodowała naruszenie spoistości gruntu w celach budowlanych. Znamy dobrze choćby przypadek miasta Bytomia na Śląsku, które nieustannie boryka się z tzw. szkodami górniczymi, czyli niezabezpieczonym odpowiednio podziemiem miasta, które zostało zbudowane na terenach pokopalnianych, czyli ponad pustkami wydrążonych chodników wydobywczych. Zabezpieczenie chodników zwłaszcza już wyeksploatowanych, nieużywanych jest kosztowne, zwłaszcza dla nierentownych kopalni. Odbija się to na zabudowie na powierzchni ponad pustkami, w której najpierw pojawiają się rysy pęknięć, po czym zabudowa zapada się w ruinę, powodując ubytki zabytkowej już tkanki miasta i straty w dobytku mieszkańców, a nawet ofiary w ludziach. Straty w trójwymiarowej strukturze miasta są jeszcze większe. Nie wiemy do końca, jakie straty finalnie osiągniemy swoją działalnością pod ziemią. Tym niemniej eksploracja podziemi zabezpieczana w możliwych granicach, które dotąd rozpoznaliśmy, wydaje się być pewniejsza dla przyszłości ludzi niż dalsze zawłaszczanie powierzchni. 
Eksploracja podziemia to wielka niewiadoma. Jednak każde działanie pionierskie wiąże się z ryzykiem. Ciągle jeszcze nie mamy wystarczającej wiedzy do pełnego zabezpieczenia skutków tunelowania. Każda kolejna akcja wymaga nie tylko badań podłoża, ale kompletnych analiz, aby móc przewidzieć bezpośrednie i dalekosiężne efekty prowadzenia wierceń. Niejednokrotnie wyznaczone trasy przebiegu linii tuneli przecinają warstwy historyczne lub natrafiają na niespodziewane znaleziska. Takie sytuacje wymagają specjalnych rozwiązań. Jak zawsze w takich przypadkach odkrywczość i pomysłowość projektantów, innowatorów i kontrola decydentów muszą przynieść optymalne rozwiązania. Naczelną zasadą obowiązującą przy poszukiwaniu dróg wyjścia jest całkowite unikanie lub absolutna minimalizacja negatywnych skutków i możliwie najkorzystniejsze wykorzystanie zmian. Takie postrzeganie wprowadził jako zasadę aktywności ludzi na Ziemi w 2000 roku ówczesny sekretarz generalny ONZ Kofi Annan, deklarując konieczność pełnego zachowania źródeł naturalnych surowców i wody pitnej oraz utrzymanie czystości powietrza dla kolejnych pokoleń. Zrozumienie konieczności odnawiania zasobów przyrody potwierdzają kolejne państwa, wprowadzając odpowiednie regulacje: np. Holandia w 2016 roku zapisała prawem niezbędność utrzymania pod kontrolą nienaruszalności naturalnych stosunków podziemnych w stopniu możliwie najwyższym. Znaczy to, że rząd wspiera wszelkie działania minimalizujące interwencje i zmiany ekologiczne zarówno na powierzchni, jak i nad i pod ziemią, potencjalnie towarzyszące działaniom rozwojowym na rzecz mieszkańców i gospodarki kraju, a przebiegające we wszystkich wymiarach tych akcji, również obejmujących całokształt podziemia. Trwa walka o minimalizację negatywnych wpływów urbanizacji na środowisko przyrodnicze. Celem ostatecznym jest uzyskanie równowagi, tzn. stanu pełnej odnawialności przyrody. Najbardziej palącym problemem miejskim jest utylizacja śmieci i oczyszczanie powietrza i ścieków.

Postindustrialna generacja infrastruktury miejskiej bazuje na proekologicznie przeprojektowanych układach. W swoim założeniu są to symbiotycznie współpracujące ekosystemy, oparte na wspólnej docelowej wizji jednego ekologicznie zasilanego całościowego systemu. Niemożliwe? Możliwe, jeśli zastosuje się konsekwentnie wszystkie już wymyślone i stale powstające usprawnienia wykorzystujące siły natury i sprytne pomysły lokalne, inwencję zapobiegliwych mieszkańców, odkrywczych racjonalizatorów i naukowców. W ten nurt wpisują się zarówno gigantyczne inwestycje miejskie, jak i drobne rozwiązania lokalne. Przykładem tych z rozmachem zaprojektowanych, jak np. New San Francisco Transbay Center, jest kilkupoziomowe pasmo usług miejskich wprowadzone pomiędzy zabudowę wieżowców centralnych miasta. Zawiera ono powiązany funkcjonalnie ciąg usług centralnych od podziemnych linii kolejowych, metra i miejskich autobusów przez podziemno-naziemną komunikację pieszą, łączącą sieci we wszystkich kierunkach, aż po rozlokowane gęsto współpracujące z nimi galerie usług o zróżnicowanym charakterze, skupiska handlu oraz ośrodki kultury, sportu i rekreacji w części nadziemnej. Cały górny poziom to zielone pasmo urządzonych parków, skwerów i przestrzeni publicznych towarzyszących usługom. Przykładem innego lokalnego działania o nieco mniejszej skali może być nieczynny już wewnętrzny port w Rotterdamie, 
w którym usytuowano urządzenia oczyszczające brudną wodę z doków portowych. Dzięki pogrążeniu oczyszczalni poniżej poziomu głównego można było przykryć całość zielonym dachem, na którym urządzono pole golfowe. Wokół rozbudowują się dzielnice mieszkaniowe z dużą ilością zieleni. Inny duży projekt niwelujący komunikacyjne uciążliwości - pogrąża pasma komunikacyjne pod ziemię i pokrywając je platformami dla pieszych, organizuje kilometry urządzonych w zieleni deptaków i rozmaitych przestrzeni publicznych, ciągnących się po obu stronach miejskiej rzeki - to Madryt i The Madrid Rio Project.

Hillary Brown, amerykańska architekt, w swojej książce nt. projektowania zrównoważonego formułuje 5 warunków do spełnienia dla projektów wpisujących się w wymogi współczesności. Są to:

1. Współzależne i synergicznie współdziałające wielozadaniowe ekosystemy (wpisanie w środowisko, miękkie włączenie w działanie sieci);

2. Zintegrowany wysiłek włożony w dekarbonizację energii;

3. Infrastruktura swobodnie płynącej wody - kombinacja naturalnych otwartych wód i konstrukcji ujmujących zbiorniki i przepływ, miękkie i konstrukcyjne umacnianie linii brzegów, zwiększenie ujęć wody, bezpieczne gromadzenie i przechowywanie wody;

4. Destygmatyzacja infrastruktury - urządzenia przyjazne człowiekowi, estetycznie zaprojektowane, nieukrywane;

5. Przemyślane globalnie drogi rozwoju, eksperymentować można lokalnie².

Wszystkie te zagadnienia mieszczą się w znajomych już hasłach - zakresach działań nie tylko ekologów, ale wszystkich „urbanistów”, czyli w szerokim pojęciu ludzi działających na rzecz miast: wykorzystanie biomasy, redukcja węgla, adaptacja do zmian klimatycznych, wyhamowanie zmian klimatu, umocnienie linii brzegowych, oszczędne (smart) systemy dystrybucji energii, zielone ulice, wodorowe paliwo, ekologia infrastrukturalna, energia odnawialna, stosowanie urządzeń użyteczności publicznej (meblowanie miasta), stosowanie smart grid - sieci oszczędzających (regulujących elektronicznie) zużycie, wykorzystanie energii słonecznej, zagospodarowanie wód deszczowych, podnoszenie wytrzymałości urbanistycznych rozwiązań, kontrolowane spalanie odpadów, regulacja niedoboru wody, detoksykacja odpadów szkodliwych, jakość wody³.

\subsection{CZY MOŻLIWY JEST MODEL ROZWOJOWY DZIAŁAŃ PODZIEMNYCH?}

Planując rozwijanie tkanki miejskiej pod ziemią, nie wystarczy zbadać geologicznego przekroju i układów nośnych w głąb wyznaczonego planistycznie obszaru w planie rozwoju miasta. To nie tylko określenie podatności na przenoszenie obciążeń konstrukcyjnych dla tego terenu, a nawet jego głębokich warstw. Zadanie jest o wiele bardziej skomplikowane. Dotyczy również geochemii obszaru, czyli na przykład składu chemicznego warstw geologicznych, w celu określenia potencjalnego zagrożenia pogorszeniem jakości ziemi uprawnej czy wpływu na zdrowie mieszkańców. Na przykład eksplorując tereny poprzemysłowe, łatwo 
skazić lub zanieczyścić duże obszary użytków miejskich. Tereny określone jako wodonośne dla ujęć wody pitnej z góry zostają wyłączone z interwencji projektowych i objęte całkowitą bezterminową ochroną. Nie potrafimy też jeszcze przewidzieć wszystkich konsekwencji naszych ingerencji podziemnych. Nie wystarczy bowiem przebadać samych ekosystemów występujących na danym terenie, ale należy poznać wszystkie systemy, które na nie oddziałują, zarówno te już pracujące, jak i te zamierzone. Takimi problemami i wytyczaniem kierunków postępowania zajmuje się specjalna sekcja powołana wyżej przytoczoną uchwałą rządową w Holandii z 2016 r. - określająca wizję podziemnego planowania przestrzennego wpisanego już w planowanie miast. Podzielono interwencje podziemne na płytkie - obejmujące działania do głębokości 200 m, i głębokie - poniżej tej granicy. Nie sposób też bardziej szczegółowo nie porządkować i nie systematyzować przebiegów sieci, planując jakiekolwiek działania podziemne, np. planując ekologiczne ogrzewanie geotermalne miasta. Musimy nie tylko określić precyzyjny przebieg planowanej sieci instalacji grzewczej, ale także wpisać go w układ już działającej, a ponadto zaprojektować jej przebieg w stosunku do wszystkich już pracujących i planowanych innych rozwijających się sieci miejskich. Grupa Think Deep w pracach ISOCARP/ITACUS nad użytkowaniem podziemi w miastach dla Hagi (Holandia) określa te przebiegi sieci warstwami. Proponuje dla konkretnych przypadków określać je trójwymiarowo, strefując w układach horyzontalnych i prowadząc warstwami wertykalnie. Ostateczny kształt zależy od warunków zrównoważonego rozwoju miejsca. Liczą się wszystkie aspekty wykorzystania, np. materiałów odpadowych, ubytku lub organizacji nowych miejsc pracy, wpływu na demografię, większe lub mniejsze zużycie lub zapotrzebowanie na dobra i produkcję itd. Nakreślenie modelu działań podziemnych może co najwyżej przybliżyć sposób postępowania, który musi być dostosowywany każdorazowo do konkretnych przypadków i uwarunkowań miejsca. The Millenium Ecosystem Assessment określił jasno, że życie ludzkie na Ziemi zależy absolutnie od sprawnego działania ekosystemów, czyli wzajemnie się wspierających i zależnych systemów naturalnych przyrody - unikalnych, bo w pełni odnawialnych, w opozycji do nieodnawialnych mineralnych, zawartych pod powierzchnią ziemi. Tym niemniej również interwencja w podziemne warstwy zmineralizowane może mieć wpływ na funkcjonowanie ekosystemów i zmianę warunków geomorfologicznych środowisk. O wszelkich zmianach w mieście należy myśleć w sposób holistyczny, warunkując wszelkie projekty dalekosiężnymi planami i ich przewidywanymi efektami. Równowaga zmian może być osiągana jedynie z zachowaniem śladów przeszłości, założeniem polepszania jakości życia współczesnego i z respektem dla przyszłości, tzn. zachowaniem niezmienionych warunków do rozwoju.

Konstrukcje budowlane, w tym tunelowanie, są rodzajem zmagań z naturą, z przeciwnościami naturalnymi, które człowiek musi pokonać, aby ułatwić sobie życie. To już nie walka o przetrwanie, lecz wyścig o rządy. O przetrwanie człowiek walczy teraz z własnym nieposłuszeństwem, kiedy nie stosuje się do wymogów równowagi środowiska. 


\section{PROJEKTOWANIE W PODZIEMIU}

Dla standardowego mieszkańca miasta podziemie miasta to własna piwnica, może jeszcze podziemny garaż dwupoziomowy, zejście do metra lub, co najwyżej, do dworcowej galerii handlowej, wiodącej korytarzem na peron pociągu. Podziemie to płytkie warstwy ukrytych pod powierzchnią usług miejskich. Tymczasem już w chwili obecnej podziemie użytkowe na przykład Londynu sięga znacznie głębiej. Dla porównania najniżej położona linia metra Bull\&Bush sięga poziomu 67 m, a jej najniższa stacja Hampstead - 58,5 m poniżej powierzchni. Nowy Lee Tunnel - tunel ścieków miejskich będący częścią schematu Thames Tideway (podstawowy tunel odpływu Tamizy to $30 \mathrm{~m}$ ) - leży na głębokości 60-70 m. Główny tunel wodny jest na głębokości $40 \mathrm{~m}$, dla porównania stabilizujące wzmocnienia pale pod stacją Liverpool to 63,4 m, a słupy pod najwyższym wieżowcem hybrydowym Shard to głębokość $55 \mathrm{~m}$. Tunel sieci energetycznej zasilający miasto leży na głębokości $35 \mathrm{~m}$. Głębokość linii metra i kolei pocztowej to poziomy między 20-25 m, tunele piesze to 15-20 m, cut-and-cover metro miejskie to zagłębienie 5-6 m, kolektory miejskie $-4 \mathrm{~m}$. Warstwa do 1,5 m pod powierzchnią to na ogół w każdym mieście plątanina najstarszych chaotycznie prowadzonych instalacji i rur, łącznie z gazowymi - niosącymi wysokie ryzyko naruszeń, wręcz katastrof przy jakichkolwiek pracach ziemnych, a to głównie ze względu na brak precyzyjnych danych dokumentujących ich prawdziwy przebieg. Jak dalece powinniśmy wobec tego ingerować w podziemie bez szkody dla bezpieczeństwa i żywotności miasta? W przypadku Londynu gros instalacji uporządkowano podczas napraw i wymiany, większość nieszczelności związanych z przestarzałą strukturą sieci instalacji zarówno gazowych, jak i wodnych - została już usunięta i zabezpieczona. W związku z dużymi stratami i zmianami ekologicznymi, jakie powodowały wycieki, w dużej mierze całkowicie już wymieniono sieci. W tej chwili Londyn należy do wiodącej grupy miast smart - oszczędnie gospodarujących dobrostanem urbanistycznym i wpisującym się w nurt proekologicznego dalszego rozwoju.

Jak jednak przełożyć tę problematykę na rzeczywistość przeciętnego miasta, nawet tylko europejskiego, średniej wielkości? Przede wszystkim trzeba pokonać bariery fizyczne i psychologiczne, które dzielą nam przestrzeń naziemną i podziemną na dwa oddzielne światy. Wielu z nas doświadczyło przecież penetracji podziemia, podróżując nawet tylko po Polsce, chociażby $\mathrm{np}$. korzystając z centrów handlowych schodzących użytkowymi poziomami do podziemia, połączonych z kolejnymi poziomami kolejki czy metra, do kin, parkingów, przejść podziemnych, wyprowadzających na bulwary rzek, place publiczne czy parki. To jest już praktyka codzienna nowoczesnego miasta - łączenie wielopoziomowych nadziemnych konstrukcji z ich oczywistym niezbędnym głębokim posadowieniem, wykorzystując „przy okazji” możliwości i mieszcząc tam kolejne poziomy użytkowe współpracujące w integralny sposób z naziemną strukturą. Dla użytkownika komunikacja pionowa i zręcznie zaprojektowane wnętrza w niezauważalny sposób prowadzą z najwyższych w najniższe partie budynków. Podobnie jak ogromne powierzchnie rozległych malli handlowych potrafią sprawić, że kompletnie się zagubimy w plątaninie alejek i przyciągających reklamami usług - chociaż poruszamy się w jednej horyzontalnej płaszczyźnie. 
Otwarty konkurs architektoniczny zorganizowany w formie publicznej wystawy przez RATP (paryski Zarząd Transportu Publicznego) na stację metra przyszłości wyłonił m.in. jedną ze zwycięskich prac, która opisywała rodzaj platformy rozrządu ruchu pieszego na pośrednim poziomie, platformy zagłębionej poniżej powierzchni, a wyprowadzającej w kierunkach kolejnych poziomów metra, kolei i innych ciągów komunikacyjnych. Usytuowana pod ziemią, ale całkowicie otwarta, z rosnącą zielenią z drzewami, łagodnie wprowadzała systemami interesująco zaprojektowanych pochylni, biegów schodów i mechanicznych urządzeń wspomagających w coraz niższe poziomy podziemne. Będąc de facto częścią infrastruktury, zaprojektowana została jak urbanistyczne wnętrze publiczne, stała się kolejną sceną dla miejskiego spektaklu, jakim jest codzienne życie.

Urbanizm to zagęszczenie i różnorodność funkcjonalna. I dlatego ważne jest włączenie „miękko” wszystkich elementów infrastruktury w codzienną, przyjazną oczywistość użycia, projektując je jako „umeblowanie” przestrzeni publicznych. Przejście do podziemia nie może odstręczać, musi się stać formą intrygującej reklamy zapowiadającej dalsze atrakcje, niespodzianki, przyjemności, musi też być znakiem rozpoznawalnym dla każdego, zachęcającym do skorzystania z ułatwień. Tak właśnie powstał projekt paryskich Hal, będących przez dziesiątki lat najbardziej demokratycznym symbolem miejskiego populizmu. Nadal jeszcze w budowie Nowe Hale utworzyły z centralnego obszaru miasta, dotąd uciążliwego i pozbawionego wszelkiej higieny zagęszczenia przestarzałego kompleksu budowli naziemnych nowoczesną platformę - węzeł komunikacyjny wielu różnych linii transportu publicznego - „odwróconą kubaturę" zapewniającą przestronne wnętrze urbanistyczne dla gęstego funkcjonalnie podziemia. Dla pełnej integracji tkanki urbanistycznej nad- i podziemia ma jeszcze zyskać zielone pokrycie o bulwarowym charakterze rekreacyjnym.

\section{PRAWO WŁASNOŚCI W OBSZARZE MIEJSKIM}

Interesując się potencjałem podziemia, odkrywamy, że pomimo przebiegających wielokierunkowo ulic i wszelkiego rodzaju ciągów komunikacyjnych, pomimo placów i innych przestrzeni publicznych, które już z samej nazwy powinny być „wspólne” lub „miejskie”, okazuje się, że większość podziemia, czyli kubatury w głąb ziemi i to nie tylko pod obrysem najbliższego otoczenia własnego budynku, ale również działek pod użytkowaną przez miasto przestrzenią - jest prywatna. Przez dziesięciolecia tworzono i doskonalono prawo, w tym prawo własności i budowlane, ale dotąd nie myśleliśmy o podziemiu jako potencjale budowlanym, a zatem marketingowym.

Rozszerzanie zintegrowanej tkanki miejskiej wielokierunkowo - to zagadnienie projektanckie, natomiast prawo do użytkowania tych struktur jest już bardziej problematyczne, ponieważ na przykład całość przestrzeni metra w Londynie jest własnością instytucji London Underground i w czasie gdy metro jest nieczynne, gdy pracownicy metra nie pracują automatycznie wejście dla publiczności się zamyka. Podobnie np. policja miejska nie obejmuje monitoringiem stacji metra, ponieważ ta działalność należy do Policji Transportu Brytyjskiego. 
Wszelkie podziemne korytarze łączące np. transport publiczny z posesjami budynków choćby tylko częściowo prywatnych również automatycznie są zamykane dla anonimowych korzystających. W tym kontekście przypuśćmy potrzebną pomoc lekarską dla ofiary nagłego przypadku w podziemiu - co zrobić, gdy ratownicy należą do sektora służb publicznych? Nawet gdy zadbano w projekcie o dostępność podziemia dla służb ratowniczych, mogą nie mieć one prawnej możliwości udzielenia pomocy klientom korzystającym z przestrzeni budynków usługowych.

W Rotterdamie akces publiczny do przestrzeni publicznych rozmieszczonych na terenie prywatnym jest prawnie zapewniony w znacznie większym stopniu. Nie zamyka się np. przejść przez obiekty usługowe będące własnością prywatną, a łączących punkty dojścia ważne dla użytkowników podczas codziennego cyklu użytkowania i z przyzwyczajenia po prostu potrzebnych. William Whyte, amerykański urbanista i socjolog, sformułował tezę (1988) nt. projektowania otwartości przestrzeni publicznych w taki sposób, żeby użytkownik korzystał z nich, przemieszczając się w swojej podróży przez miasto, wchodząc i wychodząc - całkowicie instynktownie - bez natknięcia się na bariery i zamknięte drzwi. Dlatego Nowy Jork już w 1961 r. wprowadził strefowanie dające prawo deweloperom do tworzenia placów publicznych w ramach swoich posesji. Za każdy metr kwadratowy placu deweloper dostawał dodatkowe prawo do $10 \mathrm{~m}^{2}$ powierzchni komercyjnej pod warunkiem jej stałej dostępności publicznej. Ten przywilej szybko okazał się główną atrakcją dla przedsiębiorców

\section{CIĄGI PIESZE, PASAŻE CZY TUNELE?}

Przejścia podziemne w dużych miastach tworzą niekiedy całe sieci łączące ważniejsze miejsca zainteresowania użytkowników. Podyktowane to jest nie tylko łatwiejszą dostępnością, bezpiecznym, bezkolizyjnym skrótem drogi na piechotę, np. od wybranej stacji metra czy wyjścia z centrum usługowego, ale też czynnikami klimatycznymi. Zazwyczaj jest to miejsce ucieczki od uciążliwości ostrej zimy lub upalnego lata, ulewnej burzy lub zamieci śnieżnej, bardzo istotne w tropikalnym klimacie lub zanieczyszczonym smogiem powietrzu. W Londynie czynne są nawet podziemne wejścia do muzeów: Victoria \& Albert Museum czy Natural History Museum - przez jego ogrody. Względy podniesienia bezpieczeństwa, ale i atrakcyjności podziemnych korytarzy skutkują obrastaniem ich w rozmaite usługi komercyjne, co często powoduje małą widoczność kierunkowskazów pośród reklam i zagubienie w sieci korytarzy. Stąd ważne jest specjalne oznakowanie miejsc, a dla lepszej orientacji architektom, artystom i urbanistom zleca się projektowanie charakterystycznego urządzenia i wystroju podziemnych wnętrz urbanistycznych, dedykowanych poszczególnym miejscom na powierzchni.

Ten ruch poszukujący łatwej dostępności sfery usługowej użytkowników miast oraz chęć odwrócenia powszechnego zawłaszczania terenów miejskich przez ruch samochodowy, powodujący wyniszczanie przyrody, złe samopoczucie pieszych i spore uszczerbki zdrowia, oraz chęć przywrócenia powierzchni ziemi jej mieszkańcom - ukierunkowały poszukiwania rozwiązań odwrotnych: skierowanie całego ruchu samochodowego łącznie z parkowaniem pod ziemię. 
Najlepszym przykładem jest prywatna inicjatywa firmy Strukton Civiel i architektów ZJA (Zwarts\&Jansma Architects) z Amsterdamu, którzy zaprezentowali na międzynarodowym kongresie w Amsterdamie projekt „Amfora”, nagrodzony MIPIM ${ }^{5}$ Future Project Award jako Big Urban Project w 2010 roku. Zwycięski Amfora Amstel Plan to wielkoskalowe rozwiązanie wielopoziomowego podziemnego centrum miejskiego pod rzeką Amstel w Amsterdamie. Jego realizacja została ukończona w 2018 roku. Jedynym problemem, który sprawia sporo kłopotów użytkownikom i niestety powoduje często rezygnację z korzystania z dobrodziejstw nowego centrum, jest nadmiar znaków informacyjnych. Skomplikowany układ pomieszczeń wymagał zrozumiałej, niezawodnej komunikacji. Stąd przeładowany informacyjnymi znakami i symbolami przewodni system, niepozwalający zgubić konsekwentnie prowadzonej wybranej trasy, zmuszający do stałego śledzenia oznakowania i pełnej koncentracji, powoduje często zniechęcenie sporej części użytkowników do korzystania z trudniejszych przejść.

Pierre Bélanger, opisując system pieszych dróg podziemnych w Toronto, chwali go jako najbardziej udany ${ }^{6}$. System opiera się na punktach węzłowych i łączących je osiach tworzących korytarze urbanistyczne prowadzące pieszych. Wyznaczone punkty - przestronne wnętrza usługowe - są zarazem łącznikami ze znaczącymi punktami na powierzchni. Sieć podziemna pełna jest użytkowników w ciągu tygodnia pracy, pęka w szwach w godzinach szczytu, ale w weekendy i okresy wolne od pracy - nieco zamiera. Tym niemniej warunkiem wygody użytkowania i podtrzymania zainteresowania jest zapewnienie stałego przepływu ludzi, a więc otwarcie korytarzy bez przerw i stałe funkcjonowanie przynajmniej części usług. Warunkiem zainteresowania jest oczywiście różnorodne wypełnienie programem usługowym. Warunkiem też jest kontrola bezpieczeństwa, która de facto spoczywa na właścicielu obiektu, ale nie powinna prowadzić do subiektywnej selekcji wchodzących i segregacji użytkowników powodującej poczucie wykluczenia.

Koniecznością do spełnienia dobrego funkcjonowania sieci podziemnych są według Bélangera:

1. Precyzyjne zmapowanie podziemia z uwypukleniem stref połączeń z naziemnym planem miasta;

2. Synchronizacja godzin pracy i otwarcia zespołów usługowych - zgodne z oczekiwaniami i potrzebami odbiorców, którymi są głównie okoliczni mieszkańcy poszczególnych stref;

3. Planowanie rozwoju sieci podziemnej w powiązaniu z rozwojem przestrzeni publicznych na powierzchni.

Generalnie planowanie rozwoju podziemia w mieście powinno być jednoznacznie związane i prowadzone w całości jako jedno planowanie rozwoju miasta. W dotychczasowy model tzw. masterplanów miast w naturalny sposób winno wejść planowanie rozwoju we wszystkich kierunkach: nie tylko obszarami, ale trójwymiarowo, z określeniem możliwych wysokości i głębokości prowadzenia warstw funkcjonalnych, które z kolei winny być odpowiednio określone adresowanym przeznaczeniem i prowadzeniem wewnętrznych powiązań zwrotnych.

Ogół struktury powyżej i poniżej powierzchni powinien być traktowany jako jedna współzależna całość. 


\section{CHAOS POD ZIEMIĄ - JAK GO UNIKNĄĆ?}

W wielu rozwiniętych dużych miastach na świecie istnieją już i pracują z pełną wydajnością mocno rozbudowane sieci podziemnych tuneli. W warstwie najpłytszej, do 1,5 m pod powierzchnią ziemi, na ogół kłębią się (rzadziej prowadzone w sposób usystematyzowany) wszelkie sieci uzbrojenia technicznego miasta. Głębiej pracują wielokierunkowo i wielopoziomowo rozwiązane sieci komunikacji miejskiej i dalekobieżnej - szynowej. Warstwy wodonośne wykorzystywane są w ciepłownictwie, geotermii. Aby uniknąć chaosu w dalszym rozwoju miasta zarówno nad, ale przede wszystkim pod ziemią, czyli w terenie nie zawsze i nie dość rozpoznanym, więc nieprzewidywalnym, przy zróżnicowanych potrzebach poszczególnych sieci i nowo wprowadzanych podziemnych ciągów i pasm funkcjonalnych potrzebna jest pełna legislacja prawna i jej kategoryczne respektowanie. Zabezpieczenia prawne chronią nie tylko właścicieli terenów. Obecnie potrzebna jest ochrona podziemia i prawidła użytkowania kolejnych warstw, a nawet zakleszczających się fragmentów różnych własności przebiegających nierównolegle i w różnych kierunkach względem siebie. Podobnie w abstrakcyjny sposób szuka się dzisiaj w miastach nie tyle przerw w zabudowie do „zaplombowania”, co szeroko pojętych luk w przestrzeni miasta, w każdym jego wymiarze. Wykorzystuje się szczeliny w zabudowie, przestrzenie ponad budynkami, niezagospodarowane dachy i poddasza oraz wszystkie możliwe przestrzenie do nadwieszania, podbicia zabudową, wypełnienia. Promuje się pomysłowych architektów i właścicieli wprowadzających nowe modele użytkowania i sposoby na smart udogodnienia, pozwalające małym kosztem albo w sposób ekologiczny zrewitalizować poszczególne miejsca w mieście.

Zmieniła się również skala użytkowania podziemia. W widoczny sposób na przykład różnią się współczesne zejścia do stacji metra w miastach, w których kolejki podziemne funkcjonują od początków tunelowania. W Paryżu lub w Londynie stare stacje znaczone są niewielkimi zejściami obudowanymi, zawsze takimi samymi, łatwo rozpoznawalnymi ażurowymi „budkami”, chroniącymi pojedyncze biegi schodów prowadzących do podziemnych stacji. Są jak znaki rozpoznawcze jednoznaczne dla pieszych i tak funkcjonują do dzisiaj. Obecne są jednak prawie wyłącznie w strefach śródmiejskich. W strefach bardziej odległych od ścisłego centrum, gdzie pospieszny ruch idących do pracy lub powracających z miasta, zwłaszcza w godzinach szczytu, jest natężony, projektuje się znacznie obszerniejsze zejścia. Często osiągają formę dużych wgłębników z kaskadą schodów, dodatkowo zawsze wyposażonych w mechaniczne urządzenia do ułatwienia komunikacji pionowej. Kilkukondygnacyjna przestrzeń wgłębnika łączy kolejne poziomy użytkowe stacji lub platform usługowych, tworząc poszczególne wnętrza publiczne, pasaże i wydzielone place, nierzadko obudowane drobnymi punktami usługowymi. Za przykład mogą służyć choćby rozwiązania w Canary Warf dla ww. Londynu lub analogicznie Les Halles dla Paryża.

Zmienia się również logika budowania. Konieczność dogęszczania tradycyjnie budowanego miasta na powierzchni odzwierciedla się w strategii budowania struktur podziemia. Intensywnej zabudowie naziemnej powinna odpowiadać zwarta z natury rzeczy struktura podziemnych przestrzeni zurbanizowanych. Formowana winna być tak, aby w pełni wykorzystać 
potencjał przestrzenny bez marnowania odcinków niewykorzystywanych i dla zapobieżenia pomyłkom nawigacyjnym - tak przy budowie, jak i w użytkowaniu.

Podsumowując, w ślad za myślą Bélangera opisującego kanadyjski przypadek Toronto w projektowaniu podziemnych struktur - przestrzeni urbanistycznych miasta, dla zachowania spójności części naziemnych z podziemiem musimy zachować:

1. czytelność układów,

2. dostępność i przestronność,

3. przepływ - łatwość ruchu,

4. użyteczność i elastyczność,

5. jakość wykonania.

Te wymagania odnoszą się do struktur podziemia, ale są takie same jak te odnoszące się do przestrzeni publicznych opisywanych jako place na powierzchni. Są absolutnie tożsame dla wszystkich przestrzeni publicznych. Wyobrażenie o podziemiu miasta musi być budowane wśród użytkowników i wszystkich zaangażowanych w powstawanie podziemnego miasta, dokładnie tak samo jak budujemy na bieżąco wizerunek każdej ulicy miejskiej, każdego placu, a nawet skweru z rosnącą zielenią i szemrzącą wodą.

\section{REGULACJE WŁASNOŚCI PODZIEMIA}

Bez wątpienia pierwszym krokiem dla uregulowania prawa własności jest wprowadzenie pojęcia podziemie do obowiązującego słownictwa urbanistycznego jako potencjalnego terenu budowy. Dodatkowo teren budowy generalnie powinien być wymieniony w przestrzeni budowlanej miejsca lub jednoznacznie się do niej odnosić. Niewiele miast już używa takiej terminologii w swoich działaniach miejskich. Niewiele z nich bierze w pełni pod uwage potencjał podziemia na równi z naziemnym. Niewielu urbanistów i decydentów rozumie i przestało się obawiać podziemia. Jedynym sposobem, aby w pełni zrozumieć ten potencjał i nie bać się wyobrażonej przestrzeni, która bardziej kojarzy się przeciętnemu europejczykowi, w tym Polakowi, z miejscem pochówku, domeną umarłych, w najlepszym razie z mitycznym Hadesem, jest demonstrowanie dotychczasowych rozwiązań - fotograficzny serwis miejsc na świecie, które pracują pod ziemią i coraz częściej i skuteczniej rozwiązują rosnące miejskie problemy. Bombardowani jesteśmy wiadomościami o tragicznych tąpnięciach lub wybuchach kopalnianych, ale niechętnie dochodzi do nas prawda o ekonomicznym przeliczniku nieopłacalności wydobycia. Natomiast rzadko wspominamy takie same pozostałości kopalniane, które odpowiednio zagospodarowane i zabezpieczone służą celom muzealnym, eventom artystycznym, rozmaitym zgromadzeniom kulturalnym i okazjonalnym, a w końcu względom zdrowotnym - vide choćby najbliższa nam, w dużej części wygaszona kopalnia soli w podkrakowskiej Wieliczce. Bilans korzyści z podziemia jako rezerwy przestrzeni miejskiej wychodzi jednoznacznie na plus dla rozwiązań podziemnych. 
Wydaje się oczywiste włączenie podziemia miasta w planowanie rozwoju miejskiego, zwłaszcza współcześnie w obliczu globalnych problemów i zagrożeń, na które jako świadomi obywatele nie możemy być obojętni - globalnej walki z głodem, konieczności odzyskania czystych wód, w tym powszechnego dostępu do wody pitnej, globalnych problemów takich jak pozyskiwanie czystej energii, rozwoju ekonomicznego mniejszym nakładem pracy, powszechnej infrastruktury i innowacyjnego przemysłu, zrównoważonych miast i społeczności, poprawy klimatu. Aby poprawić klimat musimy likwidować monokultury, gigantyczne farmy, transport dóbr na duże odległości, musimy się zabezpieczyć przed wyniszczającymi katastrofami powodowanymi anomaliami klimatycznymi. Podziemie daje znacznie bezpieczniejsze schronienie, odporne na katastrofalne skutki kataklizmów, daje też możliwość hodowli żywności dla miejscowych odbiorców. Japońskie doświadczenia dowodzą możliwości 100-krotnie większej produkcji czystych warzyw w farmach hydroponicznych i aeroponicznych, zamk- niętych, bez słonecznego światła. Są one samowystarczalne, zużywają 40\% mniej energii, 99\% mniej wody, produkują 80\% mniej odpadów niż uprawiane tradycyjnymi metodami. Pozostawiają mniejszy ślad węglowy i tzw. milę żywnościową, co oznacza ilość paliwa zużytego na transport z punktu produkcji do punktu przeznaczenia. Dodatkowo nie wymagają pestycydów do nawożenia. Takie farmy mogą się mieścić w każdym sztucznym pomieszczeniu, również w piwnicy miejskiej kamienicy.

Większym problemem wydaje się czysta woda lub jej kompletny brak. Nie przeżyjemy bez wody, jak również proces wegetacji bez wody jest niemożliwy. Zanieczyszczona lub skażona woda z kolei to powolna śmierć lub rozprzestrzeniające się choroby. Same odchody nieoczyszczane spowodują epidemię i śmierć. Budowa zbiorników do zbierania wody opadowej, przechowywania i oczyszczania, szara woda, powtórne jej użycie i ochrona wody pitnej, która powinna być dostępna wszystkim przez systemy dystrybucji - to podstawa gospodarki globalnej.

Kolejnym problemem jest pozyskiwanie i przechowywanie energii. Tu wykorzystuje się nawet niewielkie różnice w temperaturze wody podziemnej - dla odciążania i oszczędności energii cieplnej wykorzystywanej do ogrzewania. Innym sposobem są hybrydowe systemy ogrzewania, np. szwedzki STORM polegający na mieszanym hybrydowym współdziałaniu kilku różnych systemów, co pozwala w sumie na zaoszczędzenie większej ilości energii grzewczej.

W każdym działaniu i w każdej dziedzinie miejskiego życia opłaca się stosować najmniejsze oszczędności i usprawnienia typu smart. Per saldo dadzą one oszczędności opłacalne już na skalę światową. Ważna jest powszechna świadomość współpracy i współodpowiedzialności za przyszłość planety. Ważna jest świadomość skali zniszczeń i skali globalnych potrzeb. Nie możemy przymykać oczu na zniszczenia mające miejsce po drugiej stronie kuli ziemskiej, nie możemy zapominać, że nasze pomyłki odbijają się echem ubytków po drugiej stronie globu. 


\section{MIEĆ CZY RACZEJ BYĆ}

Żyjemy w zmieniającym się świecie, wymagającym dzisiaj przemiany sposobu gospodarowania surowcami naturalnymi, wymiany przemysłu na bardziej innowacyjny, niezużywający nieodnawialnych źródeł naszej egzystencji. Wszystkie dobra, których używamy, powinny być magazynowane i użyte powtórnie lub zagospodarowane w użyteczny sposób. Nie wolno nam marnować niczego, co może się jeszcze przydać nam lub innym, w najwyższej cenie są pomysły na atrakcyjne „przeróbki”, naprawy lub ożywcze nadawanie „drugiego życia" przebrzmiałym, zużytym lub niedoskonałym przedmiotom. Mody i trendy typu vintage, oldschool, retro itp. nie są przypadkowe i promują ponowne użycie rzeczy w dowcipnej, zmodernizowanej wersji. Moda jak zawsze wyraża kierunki najnowszych i aktualnych przemian światopoglądowych i odbija, a nawet wykorzystuje efekty poszukiwań odkrywczych np. ubrania szyte z makulatury, z materiałów biodegradowalnych, produkowanych przez mikroorganizmy itp. Nie chcemy wycinać drzew, więc wiele mebli na przykład produkuje się dzisiaj z tektury, nasącza naturalnymi impregnatami, pokrywa foliami z żelatyny itp. Najwięcej problemów natomiast sprawiają nam rozmaite rodziny plastików, które ze względu na wygodę użycia i łatwość produkcji niezwykle się zakorzeniły w naszych gospodarstwach i przyczyniają się do komfortu życia, zwłaszcza w ogromnej ofercie drobiazgów jednorazowego użytku. Wygoda życia „w drodze”, zaopatrywania się we wszystko co potrzebne „po drodze" i pozbywanie się zaraz po użyciu, aby nie obciążać plecaka, są zgodne z filozofią minimalizmu, ale nie powinny obejmować bezkrytycznie wszystkich aspektów posiadania, a w każdym razie powinny jawić się w zgodzie z nadrzędnym kierunkiem oszczędności, którym jest dążenie do utrzymania przyrodniczego status quo - równowagi naturalnej. Śmieci, które produkujemy, przekraczają wielokrotnie ilościową i jakościową możliwość utylizacji, nie mówiąc o wpływie tej utylizacji na ogólny stan równowagi przyrodniczej ziemi. Dlatego tony śmieci, zwłaszcza tych plastikowych, zanieczyszczają ogromne połacie terenów i wód, rozkładając się powoli i trując na przykład morza i oceany (dryfujące wyspy śmieci), a w nich wszystkie organizmy żywe. Łańcuch pokarmowy zjadających się wzajemnie mniejszych i większych ryb, a potem ssaków, powoli zaczyna ulegać zwyrodnieniu, przenosząc wadliwe geny na coraz bardziej kalekie potomstwo... być może nawet moda ubioru dostosuje się kiedyś do całkiem odmiennych istot, ale też być może, że po prostu nikt nie przeżyje.

\section{PRZYPISY}

1 Our Common Future (Brundtland Report), World Commission on Environment and Development, Oxford University Press, Oxford 1987.

2 H. Brown, Next Generation Infrastructure. Principles for Post-Industrial Public Works, Island Press, New York 2014. 
3 Nations Department of Economic and Social Affairs (UNDESA), 2012, [online] sustainabledevelopment.un.org (dostęp: 15.11.2019).

4 TOD Standard, wyd. 3, Institute for Transportation and Development Policy, ITDP, New York 2017, [online] www.itdp.org (dostęp: 15.11.2019).

5 MIPIM (Le Marché international des professionnels de l'immobilier) - międzynarodowa prezentacja połączona z konkursem na najlepsze rozwiązanie dla nieruchomości, odbywająca się corocznie w marcu w Cannes we Francji, towarzyszą jej wystawy, konferencja, eventy.

6 P. Bèlanger, Landscape as Infrastructure, Routledge 2016.

\section{BIBLIOGRAFIA}

Admiraal H., Cornaro A., Underground Spaces Unveiled. Planning and creating the cities of the future, ICE Publishing, Londyn 2018.

Bèlanger P., Landscape as Infrastructure, Routledge 2016.

Bloomberg M., Pope C., Climate of Hope. How Cities, Businesses, and Citizens Can Save the Planet, St. Martin's Press, New York 2017.

Broere W., Urban underground space. Solving the problems of today's cities, „Tunneling and Underground Space Technology", 55/2016, 245-248.

Brown H., Next Generation Infrastructure. Principles for Post-Industrial Public Works, Island Press, New York 2014.

Hajer M., Dassen T., Smart about Cities. Visualising the Challenge for $21^{\text {st }}$ Century Urbanism, PBL Netherlands Environmental Assessment Agency, Rotterdam 2014.

New Urban Agenda (NUA), 2017, UN, Equador, The United Nations publication, Habitat III Secretariat, A/RES/71/256*.

Our Common Future (Brundtland Report), World Commission on Environment and Development, Oxford University Press, Oxford 1987.

Rethinking the Clyde Waterfront, YPTDP, ISOCARP+itacus+TDUK, UK, Glasgow 2016.

Shanghai Manual. A Guide for Sustainable Urban Development of the $21^{\text {st }}$ Century, United Nations Department of Economic and Social Affairs (UNDESA), 2012, [online] sustainabledevelopment.un.org (dostęp: 15.11.2019).

Sterling R., Bobylev N., Urban underground space. A growing imperative: Perspectives and current research in planning and design for underground space use, „Tunneling and Underground Space Technology", 55/2016, 1-4.

TOD Standard, wyd. 3, Institute for Transportation and Development Policy, ITDP, New York 2017, [online] www.itdp.org (dostęp: 15.11.2019).

ADRES BIBLIOGRAFICZNY ARTYKUŁU: Mizia M., Projektowanie w ciasnej i wymagajqcej lokalizacji, Przestrzeń/Urbanistyka/Architektura, $1 / 2020$, s. 25-38.

DATA AKCEPTACJI OSTATECZNEJ WERSII DO OPUBLIKOWANIA: 13.02.2020. 